\title{
PEMBENTUKAN POSITIONING DENGAN VIDEO BACA \#TWEETJAHAT PASANGAN ANIES-SANDI SEBAGAI STRATEGI POLITICAL MARKETING MELALUI SOSIAL MEDIA
}

\author{
Tri Susanto ${ }^{1}$, Reka Prakarsa Nur Muhamad ${ }^{2}$, Satria Ali Syamsuri ${ }^{3}$ \\ ${ }^{1,2,3}$ Prodi Ilmu Komunikasi Fakultas Ilmu Sosial dan Ilmu Politik \\ Universitas Singaperbangsa Karawang \\ Email: tri.susanto@staff.unsika.ac.id
}

\begin{abstract}
Abstrak
Political Marketing adalah salah satu kegiatan dalam proses pemilihan Yang digunakan sebagai proses dalam memperkenalkan kandidat kepada masyarakat dengan metode marketing. Pasangan anies -sandi menggunakan political marketing dalam pembentukan positioning yaitu Tindakan untuk menancapkan citra tertentu kedalam benak para pemilih agar tawaran produk politik dari kandidiat pemilihan yang memiliki posisi khas, yang mencari jendela di dalam otak pemilih (Nursal:2004) melalui video baca \#tweetjahat di media sosial. Strategi \#tweetjahat ini mendapat respon positif dari masyarakat yaitu menanggapi tweet yang tidak baik dan menjatuhkan kedalam hal yang humoris. Penelitian ini bertujuan untuk mengetahui dan mendeskripsikan strategi komunikasi kampanye melalui media sosial Penelitian ini merupakan penelitian kualitatif dengan strategi studi kasus yang mengambil aktivitas kampanye di media sosial Akun@aniesbaswedan dan @sandiuno di Instagram. Temuan penelitian memberikan gambaran Strategi Komunikasi politik dengan pendekatan marketing melalui media sosial dalam pembentukan positioning yang baik pada calon pemimpin dalam Kampanye Pemilihan gubernur DKI Jakarta dengan membaca \#tweetjahat membentuk positioning Anies -sandi sebagai pasangan pemimpin yang humoris, sabar dan ramah.
\end{abstract}

Kata Kunci : Political marketing, Kampanye, Positioning, \#tweetjahat

\section{PENDAHULUAN}

Indonesia merupakan negara demokrasi yang keputusan tertinggi berada di tangan rakyatnya. Pemilukada (pemilihan umum kepala daerah) adalah salah satu bentuk dari demokrasi. Dalam 19 tahun terakhir ini demokrasi sudah dikenal hampir di seluruh Negara di dunia, bukan hanya menjadi simbol perjuangan Negara melainkan telah manjadi pahlawan setiap bangsa yang berhasil meruntuhkan sistem otoriterisme.

Political marketing adalah salah satu kegiatan yang perlu dilakukan dalam proses pemilihan. Political marketing digunakan sebagai proses dalam memperkenalkan kandidat kepada masyarakat agar masyarakat mengenal kandidat tersebut. Jika kandidat sudah dikenal oleh masyarakat, memudahkan kandidat dalam menyampaikan pesannya, dengan begitu mempermudah kandidat tersebut dalam memperoleh suara. Oleh karena itu political marketing merupakan kegiatan yang harus dilakukan kandidat sebelum kandidat tersebut ikut serta dalam kegiatan politik. 
Secara sederhana political marketing atau pemasaran politik dapat didefinisikan dengan pengertian, aplikasi prinsip-prinsip pemasaran dalam kampanye politik yang beranekaragam individu, organisasi, prosedur-prosedur dan melibatkan analisis, pengembangan, eksekusi dan strategi manajemen kampanye oleh kandidat, partai politik, Pemerintah, pelobi, kelompok-kelompok tertarik tertentu yang bisa digunakan untuk mengarahkan opini publik pengembangan dari ideologi mereka sendiri. Melihat definisi sederhana ini, maka dalam praktiknya pelaksanaan political marketing bukanlah hal baru, bagi Indonesia.

Penggunaan metode marketing dalam bidang politik dikenal sebagai political marketing. Dalam politicalmarketing, yang ditekankan adalah penggunaan pendekatan dan metode marketing untuk membantu politikus dan partai politik agar lebih efisien serta efektif dalam membangun hubungan dua arah dengan konstituen dan masyarakat. Menurut O'Shaughnessy politik berbeda dengan produk retail, sehingga akan berbeda pula muatan yang ada di antara keduanya. Politik terkait erat dengan pernyataan sebuah nilai (value). Jadi, isu politik bukan sekedar produk yang diperdagangkan, melainkan menyangkut pula keterikatan simbol dan nilai yang menghubungkan individu-individu. (Firmanzah, 2012 : 128).

Political marketing juga diterapkan oleh pasangan Anies Baswedan dan Sandiaga Uno. strategi political marketing untuk membentuk Positioning Tim pemenangan AniesSandi sukses dilakukan terbukti berhasil terlihatdari perolehan suara pasangan Calon ini diputaran pertama $42,05 \%$, sedangkan diputaran kedua $57.95 \%$ dan terpilih menjadi Gubernur DKI Jakarta dalam Pemilukada. positioning, adalah tindakan untuk menancapkan citra tertentu kedalam benak para pemilih agar tawaran produk politik dari suatu kontestan yang memiliki posisi khas, yang jelas mencari jendela di dalam otak dalam pemilihan (Nursal, 2004 : 296-300).

Positioning yang dilakukan pasangan Anies-sandi dalam membangun image sebagai calon calon gubernur yang menghadapi lawan incumbentmembutuhkan strategi yang harus kuat. Salah satu strategi yang dilakukan melalui social media dengan konten yang menarik anies-sandi memadukan konsep yang humoris yaitu dengan membaca twiter dari para hateryang memberikan tanggapan, hinaan, gambar, bahkan berita yang menjatuhkan elektabilitas Anies-sandi.

Twit jahat merupaka sebutan twit yang menjatuhkan yang ditujukan kepada seseorang atau lembaga. Dalam politik penggunaan twitter sangat penting karena menjadi salah satu saluran komunikasi politik. Memadukan twit jahat dari hater dengan membangun positioning merupakan hal yang baru dalam kampanye politik, yaitu dengan membuat video yang khusus menanggapi twit jahat dan di sebar kembali ke media sosial. Video ini sendiri dikemas tim anies-sandi dengan konsep humoris dengan menanggapi twit jahat dengan gaya humor dapat meningkatkan elektabilitas anies-sandi di media sosial sebagai pasangan yang humoris, ramah, lucu dan tidak marah ketika di jatuhkan melalui sosial media.

Beragam tanggapan dalam membentuk positioning yang dilakukan anies-sandi dalam kampanye baca \#tweetjahat sangat beragam sehingga Dari latar belakang diatas rumusan masalah dalam penelitian ini adalah :

1. Bagaimana Strategi political marketing pasangan anies baswedan- sandi uno dalam membentuk positioning melalui sosial media?

2. Bagaimana tanggapan dalam video \#tweetjahat mempengaruhi pemilih dalam Pilkada DKI Jakarta?

\section{METODE PENELITIAN}


Dalam penelitian ini peneliti menggunakan metode penelitian kualitatif dan pendekatan penelitiannya adalah studi kasus. Pendekatan kualitatif adalah penelitian yang bermaksud untuk memahami fenomena tentang apa yang dialami oleh subjek penelitian misalnya perilaku, perseosi, motivasi, tindakan dan lain-lain secara holisik dan dengan cara deskripsi dalam bentuk kata-kata dan bahasa, pada suatu konteks khusus yang alamiah dan dengan memanfaatkan berbagai metode alamiah (Moleong, $2011: 6$ ).

Yin (dalam Fachrul 2015:163), studi kasus adalah pencarian pengetahuan secara empiris yang menyelidiki fenomena dalam konteks kehidupan nyata, bilamana: batas-batas antara fenomena dan konteks tidak tampak dengan tegas; dan dimana multisumber bukti digunakan Penelitian ini bertujuan untuk mengetahui dan mendeskripsikan strategi komunikasi kampanye melalui media sosial Penelitian ini merupakan penelitian kualitatif dengan strategi studi kasus yang mengambil aktivitas kampanye di media sosial Akun $@$ aniesbaswedan dan @ sandiuno di Instagram

\section{HASIL DAN PEMBAHASAN}

Political marketing adalah konsep permanen yang harus dilakukan terus-menerus oleh sebuah partai politik atau kontestan dalam membangun keprcayaan dan image public (Butler \& Collins, Dalam Firmanzah 2012: 158). Membangun kepercayaan dan image ini hanya bisa dilakukan melalui hubungan jangka panjang, tidak hanya pada masa kampanye. Dalam membentuk perkembangan hubungan jangka panjang, perlu adanya proses untuk membangun kepercayaan, maupun itu melalui produk ataupun kelebihan, bukan hanya pada saat kampanye berlangsung untuk membentuk kepercayaan jangka panjang.

Lees-Marshmant mengungkapkan Political Marketing harus dilihat secara komprehensif). Pertama, political marketing lebih daripada sekadar komunikasi politik. Kedua, political marketing diaplikasikan dalam seluruh proses organisasi partai politik. Tidak hanya tentang kampanye politik tetapi juga sampai pada tahap bagaimana memformulasikan produk politik melalui pembangunan simbol, image, platform dan program yang ditawarkan. Ketiga, political marketing menggunakan konsep marketing secara luas, tidak hanya terbatas pada teknik marketing, namun juga sampai strategi marketing, dari teknik publikasi, menawarkan ide dan program, serta desain produk sampai ke market intelligent dan pemrosesan informasi. Keempat, political marketing melibatkan banyak disiplin ilmu dalam pembahasannya, seperti sosiologi dan psikologi. Misalnya produk politik merupakan fungsi dari pemahaman sosiologis mengenai simbol dan identitas, sedangkan faktor psikologisnya adalah kedekatan emosional dan karakter seorang pemimpin, sampai ke aspek rasionalitas platform partai. Kelima, konsep political marketing bisa diterapkan dalam berbagai situasi politik, mulai dari pemilihan umum sampai ke proses lobi di parlemen (Firmanzah 2012:198).

Dalam hal strategi komunikasi politik, marketing mengajarkan bagaimana partai politik bisa mendiferensiasikan produk dan image politiknya. Dengan begitu, masyarakat luas akan dapat mengenali identitas masing-masing partai politik dan kontestan peporangan.

Niffenneger (1989) dan Butler \& Collins (1993) menjelaskan karakteristik political marketing dengan lebih rinci. Karakteristik dan content political marketing berbeda dengan marketing komersial. Meskipun proses marketing komersial, namun hal-hal yang dibahas di tiap tahapan proses sangan berbeda antara marketing komersial dengan political marketing.

Penerapan 4P bauran marketing di dalam dunia politik sebagai berikut.

\section{a. Produk}

Menurut Niffenneger (dalam Firmanzah, 2012:200), produk (product) yang ditawarkan institusi politik merupakan sesuatu yang kompleks, di mana pemilih akan 
menikmatinya setelah sebuah partai atau seorang kandidat terpilih. Menurut Dermody \& Scullion (dalam Firmanzah, 2012:200), arti penting sebuah produk politik tidak hanya ditentukan oleh karakteristik produk itu sendiri. Pemahaman pemilih juga memainkan peranan penting dalam memaknai dan menginterpretasikan sebuah produk politik. Niffennegger (dalam Firmanzah, 2012:200), membagi produk politik dalam tiga kategori, (1) party platform (platform partai), (2) past record ( catatan tentang halhal yang dilakukan di masa lampau), dan (3) personal characteristic (ciri pribadi). Produk utama dari sebuah institusi politik adalah platform partai yang berisikan konsep, identitas ideologi, dan program kerja sebuah institusi politik.

b. Promosi

Sebagian besar literature dalam political marketing membahas cara sebuah institusi politik dalam melakukan promosi (promotion) ide, platform partai dan ideology selama kampanye Pemilu. Tidak jarang institusi politik bekerja sama dengan sebuah agen iklan dalam membangun slogan, jargon dan citra yang akan ditampilkan. Menurut Rothchild , menunjukkan pilihan media merupakan salah satu faktor penting dalam penetrasi pesan politik ke publik. Mengetahui adanya perbedaan tingkat penetrasi media (TV, radio, media cetak seperti Koran dan majalah) dalam suatu wilayah penting dilakukan untuk menjamin efektivitas pesan politik yang akan disampaikan. Promosi juga bisa dilakukan oleh institusi politik melalui debat di TV, (Firmanzah 2012:201-204).

c. Harga

Harga dalam political marketing mencakup banyak hal, mulai ekonomi, psikologis sampai ke citra nasional (Niffenegger, dalam Firmanzah 2012:205). Harga ekonomi meliputi semua biaya yang dikeluarkan institusi politik selama periode kampanye. Dari biaya iklan, publikasi, biaya 'rapat-akbar' sampai ke biaya administrasi pengorganisasian tim kampanye. Harga psikologis mengacu pada harga persepsi psikologis, misalnya apakah pemilih merasa nyaman dengan latar belakang-etnis, agama, pendidikan, dan lain-lain-seorang kandidat presiden.

d. Tempat

Tempat (place) berkaitan erat dengan cara hadir atau distribusi sebuah institusi politik dan kemampuannya dalam berkomunikasi dengan para pemilih atau calon pemilih (Niffenegger, dalam Firmanzah 2012:207). Kampanye politik memang harus bisa menyentuh segenap lapisan masyarakat. Hal ini bisa dicapai dengan melakukan segmentasi public (Niffnegger, Smith \& Hirst, dalam Firmanzah 2012:207).

Segementasi atau pemetaan ini penting dilakukan mengingat institusi politik diharapkan dapat selalu hadir dalam berbagai karakteristik pemilih. Hadir tidaknya suatu institusi politik selalu diartikan sebagai keberadaan fisiknya ditengah-tengah masyarakat, misalnya melalui kunjungan ke daerah-daerah terpencil. Kehadiran yang dimaksud disini lebih diartikan sejauh mana institusi politik dituntut untuk bisa membuat program yang bisa memuaskan segenap lapisan untuk memperoleh dukungan suara sebesar mungkin.

Smith dan Hirst (dalam Firmanzah 2012:210) juga sependapat bahwa institusi politik perlu melakukan segmentasi politik. Menurut mereka, perlunya segmentasi disebabkan oleh beberapa hal. Pertama, tidak semua segmen pasar harus dimasuki. Hanya segmen-segmen pasar yang memiliki ukuran dan jumlah signifikanlah yang sebaiknya diperhatikan. Kedua, sumberdaya partai politik bukanlah tidak terbatas. Seringkali partai politik harus melakukan aktivitas yang menjadi prioritas utama saja mengingat keterbatasan sumberdaya. Yang ketiga terkait dengan efektivitas program komunikasi politik yang akan dilakukan. Masingmasing segmen memiliki ciri dan karakteristik yang berlainan. Hal ini juga menuntut bahwa 
pendekatan yang akan dilakukan juga harus dibedakan (diferensiasi) anatara yang ditujukan kepada satu kelompok masyarakat dengan kelompok yang lain. Keempat, segmentasi ini perlu dilakukan dalam iklim persaingan partai politik. Harus ada analisis yang membedakan strategi bersaing antara satu partai politik dengan partai lainnya.

Segmentasi dengan positioning adalah dua hal yang tidak dapat dipisahkan satu dengan yang lain. Segmentasi sangat dibutuhkan untuk dapat mengidentifikasikan karakteristik yang muncul di setiap kelompok masyarakat. Sementara positioning adalah upaya untuk menempatkan image dan produk politik yang sesuai dengan masing-masing kelompok masyarakat. Setiap kelompok masyarakat tersusun dari individu-individu yang memiliki ciri, kepribadian, harapan, aspirasi dan tujuan yang kurang lebih sama.

Positioning dalam marketing di definisikan sebagai semua aktivitas untuk menanamkan kesan di benak para konsumen agar dapat membedakan produk dan jasa yang dihasilkan oleh organisasi bersangkutan. Dalam positioning, atribut produk dan jasa yang dihasilkan akan direkam dalam bentuk image yang terdapat dalam sistem kognitif konsumen. Semakin tinggi image yang direkam dalam benak konsumen, semakin mudah pula mereka mengingat image produk dan jasa bersangkutan.

Dalam suatu kampanye, semua calon gubernur dan calon wakil gubernur memilki sebuah strategi kampanye. Pasangan calon gubernur dan calon wakil gubernur DKI Jakarta yaitu Anies baswedan dan Sandiaga uno memiliki sebuah program kampanye baca \#Tweetjahat yang dibuat untuk membalas sebuah serangan jahat terhadap anies - sandi.

Anies dan Sandiaga diusung koalisi dua partai yakni Gerindra dan PKS.Anies Baswedan yang memiliki latar belakang akademisi dan sandiaga uno yang memiliki latar belakang pengusaha menjadi calon pasangan pilgub dan cawagub yang kuat untuk menyaingi lawan dari paslon gubernur sebelumnya, pasangan ini mengusungakan visi misi menjadikan Jakarta, jadi kota yang maju lestari dan berbudaya yang warganya terlibat dalam keberadaban, keadilan, dan kesejateraan bagi semua. Anies dan Sandi mengusungakan program kerja andalan yaitu OK OCE (One Kecamatan, One Center of Entrepreneurship), dimana program tersebut ialah bagaimana mencetak wirausaha baru di DKI agar dapat menjadi benchmark di daerah lain.

Karakter kandidat lawan Pasangan Anies-sandi pada putaran ke-2 periode 2017 2022 memiliki karakter yang kuat yaitu ahok yang dikenal keras dan tegas, memiliki gaya bicara yang ceplos,menjadi kekuatan Untuk menghadapi lawan dari pasangan pilgub lainnya, anis - sandi memiliki salah satu strategi kampanye dengan program kampanyenya yaitu "baca \#tweetjahat" yang di siarkan di akun resmi instagram, twitter, dan youtube milik anies baswedan. Tujuan kampanye \#tweetjahat adalah merespon secara santai serangan-serangan yang ada di media sosial. Twet jahat sekaligus memberikan pelajaran kepada netizen yang melontarkan cacian. Menurut anies ejekan dan penyerangan terhadapnya bukan lagi hal baru. Pada zaman dahulu, ejekan hanya tersebar dari mulut ke mulut. Namun dengan perkembangan media sosial memungkinkan semua orang dapat memperoleh informasi termasuk ejekan dan fitnah.

\section{Strategi promosi kampanye politik dengan program Baca \#Tweetjahat}

Adapun skema pelaksanaan program kampanye Media "Baca \#Tweetjahat yang dilakukan Pasangan Calon Gubernur dan Calon Wakil Gubernur DKI Jakarta 2017 Anies Baswedan dan Sandiaga Uno sebagai berikut : 


\section{Baca \#tweetjahat}

Pesan Kampanye : "Pembentukan Positioning karakter dari pasangan calon gubernur dan calon wakil gubernur Anies Baswedan dan Sandiaga Uno di PILKADA DKI Periode 2017 - 2022

1. Baca \#Tweetjahat dengan caption yang menarik dengan menanggapi twit yang di mention masyarakat dengan cara humoris dan unik

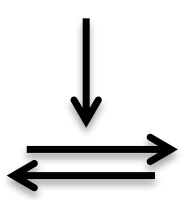

1. Instragram

2. Tweeter

3. Youtube

Bagan 1. Kegiatan Kampanye Media

Adapun beberapa video twit jahat yang di buat :

\begin{tabular}{|c|c|c|}
\hline No & Judul dan twitt jahat & Waktu Posting \\
\hline 1 & $\begin{array}{l}\text { Caption : Pasangan hidup yang tepat dapat membuat hati } \\
\text { tenang dan membantu kitamelihat sisi positif dalam segala } \\
\text { hal. Semoga } 2017 \text { jadi tahun yang manis buat kita semua } \\
\text { dan teman - teman yang masih single dapat menemukan } \\
\text { belahan jiwanya. Ada Amin? } \\
\text { Tweetjahat dari Danny Spencer : ANIS = mANIs } \\
\text { Sementara }\end{array}$ & $\begin{array}{l}27 \quad \text { Desember } 2016 \quad \text { Akun } \\
\text { Instragam @aniesbaswedan }\end{array}$ \\
\hline 2 & $\begin{array}{l}\text { Caption : No Comment saja ya...takut bikin bau } \\
\text { Twit jahat dari anna Siregar : aduh Si anies Mulut Ta** }\end{array}$ & $\begin{array}{l}10 \text { Januari } 2017 \quad \text { Akun } \\
\text { Instagram @ aniesbaswedan }\end{array}$ \\
\hline 3 & $\begin{array}{l}\text { Caption : di sela kesibukan, pintar-pintar cari waktu } \\
\text { istirahat \#tweetjahat } \\
\text { Tweetjahat dari Kamari bin nasir : Saat jadi mentri } \\
\text { @aniesbaswedan kerjanya Cuma tidur saja }\end{array}$ & $\begin{array}{l}31 \quad \text { Januari } 2017 \text { Akun } \\
\text { Instagram @aniesbaswedan }\end{array}$ \\
\hline 4 & $\begin{array}{l}\text { Caption : Sebenarnya bukan admin, tapi sodara sesebapak } \\
\text { @lambe_turah :D } \\
\text { Tweetjahat dari @ citramei_: Aku yakin banget, ternyata } \\
\text { selama ini pak Anies adminnya Lambeturah. Nyinyirnya } \\
\text { ngeselin. \#Debat2PilkadaDKI }\end{array}$ & $\begin{array}{lcc}2 & \text { Februari } 2017 \text { Akun } \\
\text { Instragam @ aniesbaswedan }\end{array}$ \\
\hline 5 & $\begin{array}{l}\text { Caption : Mas@ @okoAnwar, saya kasih tebak - tebakan } \\
\text { balik ya ... :D } \\
\text { Tweetjahat dari @ JokoAnwar : Bus apa yang DP-nya } 0 \\
\text { persen, Bus wedan Anies. }\end{array}$ & $\begin{array}{l}7 \text { Maret } 2017 \text { Akun Instragam } \\
\text { @aniesbaswedan }\end{array}$ \\
\hline 6 & $\begin{array}{l}\text { Caption : \#tweetjahat ini paling enak ditonton sambil } \\
\text { sarapan suburbur ...: :) } \\
\text { Tweetjahat dari @ @uburbur : Akhirnya kita memahami } \\
\text { kenapa @aniesbaswedan dipecat sebagai menteri. Presiden } \\
\text { tdk jelaskan. Kita paham sendiri betapa memuakan orang } \\
\text { itu. }\end{array}$ & $\begin{array}{l}\text { 21 Maret } 2017 \text { Akun Instagram } \\
\text { @ Aniesbaswedan }\end{array}$ \\
\hline 7 & $\begin{array}{l}\text { Caption : Sayang sekali yang bantu baca \#tweetjahat ini, } \\
\text { bro @achmadmunawar.id belum bisa gabung grup IBLIS. } \\
\text { Tweetjahat @SundaElfrida : @ aniesbaswedan manusia } \\
\text { berhati iblis. }\end{array}$ & $\begin{array}{l}28 \text { Maret } 2017 \text { Akun Instagram } \\
\text { @ Aniesbaswedan }\end{array}$ \\
\hline 8 & $\begin{array}{l}\text { Caption : \#Tweetjahat kali ini agak gurih - gurih gimana } \\
\text { gitu.:) }\end{array}$ & $\begin{array}{l}4 \text { April } 2017 \text { Akun Instagram } \\
\text { @ Aniesbaswedan }\end{array}$ \\
\hline
\end{tabular}




\begin{tabular}{|c|c|c|}
\hline & $\begin{array}{l}\text { Tweetjahat dari@Ghazisadikin : Pak Anies kan cagub } \\
\text { dadakan. Ya harap maklum lah yg keluar dari mulutnya } \\
\text { segitu doing. :D }\end{array}$ & \\
\hline 9 & $\begin{array}{l}\text { Caption : I'm Dan, Baswedan. Bir Pletok, shaken, not } \\
\text { stirred. B-) } \\
\text { Tweetjahat dari @indrawati23 : Liat pak anies berasa liat } \\
\text { mantan yang sudah berubah menjadi orang yang sudah } \\
\text { tidak kita kenal lagi. Sakitnya luar biasa. }\end{array}$ & $\begin{array}{l}15 \text { April } 2017 \text { Akun Instagram } \\
\text { @ Aniesbaswedan }\end{array}$ \\
\hline 10 & $\begin{array}{l}\text { Caption: Ya ampun mbak Nong ini maksudnya apa? } \\
\text { Tweetjahat dari@ @ongandah : Ya ampun mas Sandi ini } \\
\text { maksudnya apa? }\end{array}$ & $\begin{array}{l}15 \text { April } 2017 \text { Akun Instagram } \\
\text { @ Aniesbaswedan }\end{array}$ \\
\hline 11 & $\begin{array}{l}\text { Caption : Baiklah, saya tidak nyalon di daerah lain. :) } \\
\text { \#tweetjahat } \\
\text { Tweetjahat dari @Dongengwayang : kalo kalah di DKI } \\
\text { jangan nyalon di daerah lain ya pak biar pilkada adem. }\end{array}$ & $\begin{array}{l}15 \text { April } 2017 \text { Akun Instagram } \\
\text { @ Aniesbaswedan }\end{array}$ \\
\hline
\end{tabular}

1. Dalam video "baca \#tweetjahat" pada seri yang berjudul "I'm Dan, Baswedan. Bir Pletok, Shaken, Not Stirred" membalas cuitan dari akun@indriwati23 yang mengatakan "Liat pak anies berasa liat mantan yang sudah berubah menjadi orang yang tidak kita kenal lagi. Sakitnya Luar Biasa." Anis menanggapi tweet tersebut dengan memperagakan parodi dari film james bond 007.

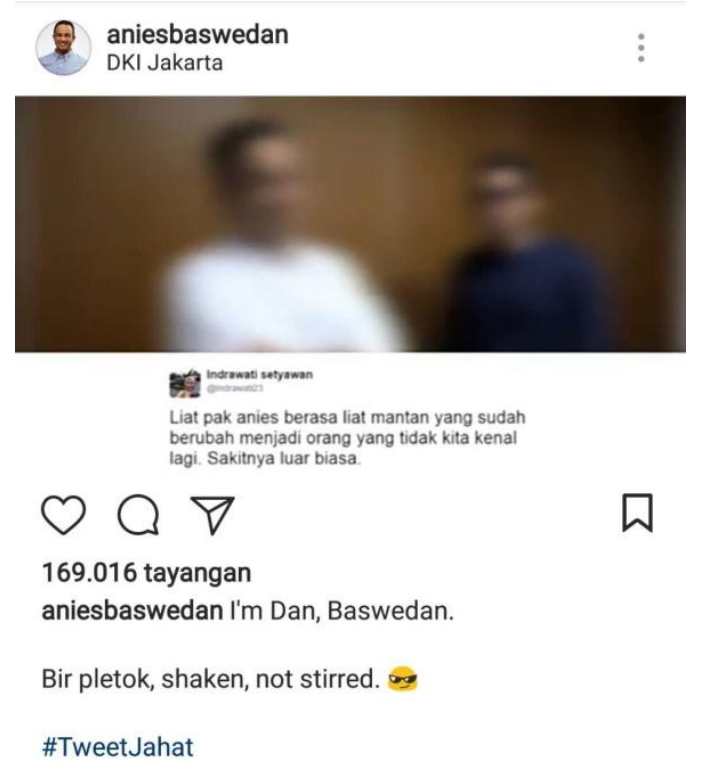

Gambar 1. 1Vidio "Baca \#Tweetjahat : I'm Dan, Baswedan" (Sumber : Instragram/aniesbaswedan)

Pada vidio tersebut anis menggambarkan bahwa dirinya telah berubah dari yang sebelum - sebelumnya. Pada vidio tersebut anis menjawab pesan yang di sampaikan salah satu komunikator yang mengatakan "Do you know her?", dan anis pun mengatakan “I don't know her”. Padahal Maksud dari @indrawati adalah kenapa anies pindah haluan yang dahulunya menteri dan tim sukses jokowi sekaran mencalonkan dirinya sebagai Gubernur DKI dan bergabung dalam koalisi Partai Gerindra, Maknanya ialah Anies tetap anies baswedan tetapi dengan gayanya yg sekarang. 
2. Video baca \#Tweetjahat "Ya Ampun mbak Nong ini maksudnya apa?" yang dipublikasikan oleh akun resmi Instagram, Twitter, dan Youtube Anies Baswedan, pasangan pilgub DKI Jakarta No urut 3 memberikan tanggapan terhadap tweet jahat dari @ nongandah tersebut. Anis di dalam vidio tersebut dengan santainya ia menanyakan langsung kepada sandiaga uno yang menjadi wakilnya di dalam pemilihan pilgub DKI Jakarta dengan mengakatan "Ya ampun, Mas Sandi ini maksudnya apa?", tetapi sandi meanggapinya dengan ekspresi gembira dan mengatakan "Yang itu, tapi saya terimakasih banget loh sama nongandah karena gara - gara tweet itu menurut Tim Survey kita yang tidak pernah di rilis itu elektabilitas kita malah justru naik".

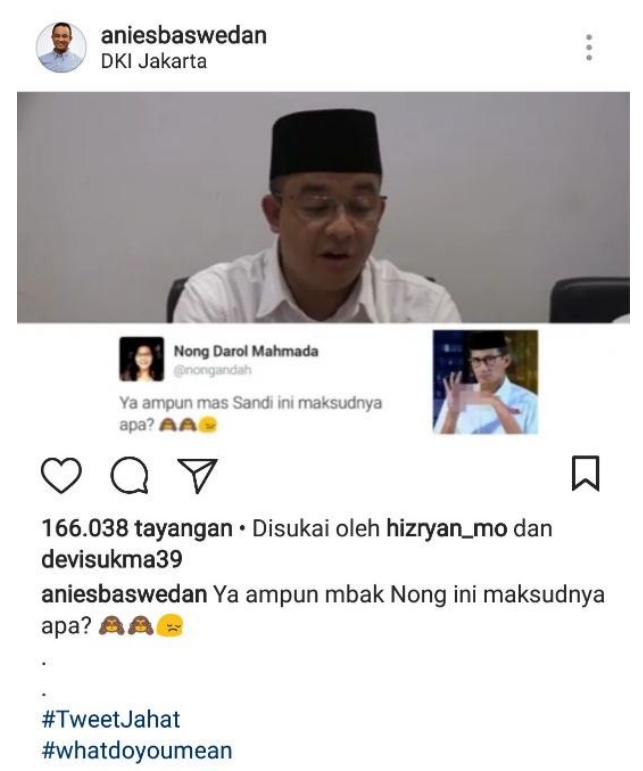

Gambar 1. 2 Vidio baca \#Tweetjahat : Ya ampun mbak Nong Ini maksudny apa? (Sumber : Instagram.com/aniesbaswedan)

Maksud sandiaga uno didalam vidio tersebut, walaupun foto itu terkesan menjatuhkan dirinya tetapi justru sebaliknya, hal itu membuat dirinya menjadi viral dan elektabilitas pada dirinya menjadi naik. Tidak hanya itu sandiaga uno yang menanggapi tweet tersebut, anis pun menanggapinya secara humoris dengan mengedit foto sandiaga uno tersebut menjadi sebuah meme.

\section{Efek Program Baca \#Tweetjahat terhadap Netizen yang mempunyai hak pilih di pilgub DKI}

Harga dalam konteks marketing politik yaitu lebih kearah emotional value yang diberikan oleh konstituen (dalam hal ini Netizen yang memiliki hak suara di DKI) kepada Kandidat (dalam hal ini Anies - Sandi). Dengan membuat sebuah vidio baca \#tweetjahat yang dibuat sebagai strategi kampanye Anies - Sandi pesan yang disampaikan vidio tersebut mendapatkan efek positif dari netizen yang menonton vidio tersebut, sebagian besar menyukai karakter anies yang terkesan humoris, sabar dan bersahaja. 


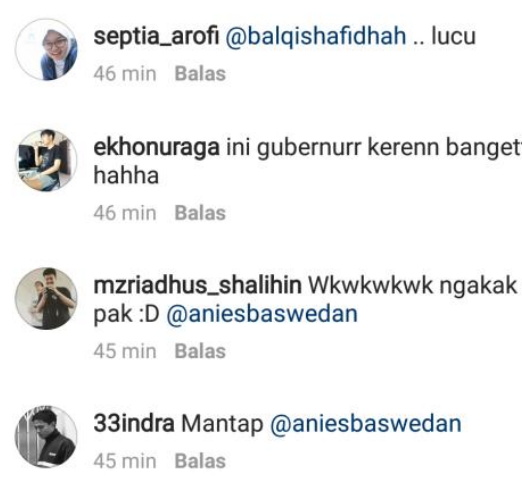

Gambar 1. 3 Berbagai tanggapan netizen terhadap Vidio Baca \#TweetJahat (Sumber : Instagram/aniesbaswedan)

Dalam Vidio baca \#tweetjahat dengan caption I'm Dan, Baswedan. Sebagian besar netizen memberikan tanggapan yang positif, banyak netizen yang beranggapan bahwa sikap anies dalam vidio tersebut sangat humoris serta keren karena anies bisa memparodikan tokoh James Bond 007. Sama halnya dengan tanggapan Netizen terhadap vidio dengan caption "Ya Ampun mbak Nong ini maksudnya apa?" mereka menilai seorang anies baswedan ternyata memiliki selera humor.

Untuk mencapai sebuah keberhasilan dalam kontes politik, harus lah dapat menarik sebuah suara dari masyarakat. untuk meraih sebuah keberhasilan seorang kandidat harus menggunakan sebuah strategi dalam mengemas suatu pesan politik dan menyesesuaikan pesan dengan isu - isu politik yang sedang berkembang di dalam masyarakat. Efek dari



program kampanye ini mendapatkan respon positif dari netizen dan banyaknya netizen yang melihat vidio tersebut sehingga membentuk pandangan mereka terhadap karakter anies dan sandi yang terkesan humoris, sabar dan bersahaja. Program kampanye "baca \#tweetjahat" ini juga bertujuan untuk memenangkan suara didalam pemilu gubernur DKI Jakarta periode $2017-2022$. 


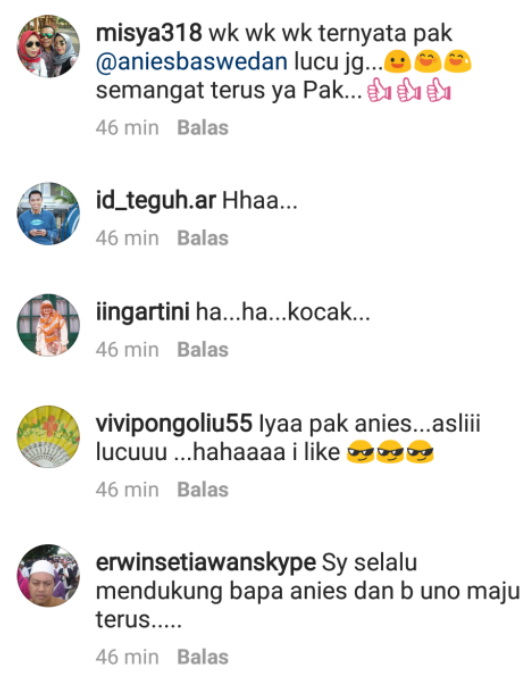

Gambar 1. 3 Berbagai tanggapan netizen terhadap Vidio Baca \#TweetJahat (Sumber : Instagram/aniesbaswedan)

\section{Media sosial sebagai sarana untuk mengkampanyekan Program baca \#Tweetjahat}

Menurut Sandra (2013) setiap pengguna media sosial termasuk didalamnya politisi dapat memproduksi pesan dengan publik yang lebih terarah karena tersedianya stimulus teknologi yang modern selama kampanye untuk menjalin hubungan kembali dengan pemilih. Teknologi Informasi serta pengemasan isi pesan yang semakin maju mengakibatkan terbukanya media sehingga mempermudah para aktor politik untuk membentuk citra mereka. Dengan maksud mengulangi kesuksesan pasangan Cagub dan Cawagub pada pemilu sebelumnya yang memanfaatkan media sosial sebagai sarana untuk membangun citra. Strategi ini dilakukan kembali oleh pasangan Cagub dan Cawagub DKI Jakarta 2017 yaitu pasangan Anies - Sandi .

Tweet jahat yang ditujukan kepada pasangan calon gubernur dan calon wakil gubernur anis - sandi di awali dari media sosial yaitu twitter. Twitter menjadi sebuah awal dari serangan komentar negatif dari berbagai netizen yang menurunakan kredibilitas seorang pasangan calon gubernur dan wakil gubernur Anies Baswedan dan Sandiaga Uno. Dalam hal ini Tim Sukses dari Anis Baswedan dan Sandiaga Uno memilih media sosial Twitter, Instagram dan Youtube dari akun resmi Anis Baswedan yang dipilih sebagai sarana mempromosikan kembali citra yang sedang mereka buat, dn hal itu cukup berhasil dan turut andil dalam kemenangan pasangan ini dalam PILKADA DKI 2017.

\section{KESIMPULAN}

Political marketing merupakan kegiatan politik yang dilakukan dengan menerapkan prinsip - prinsip marketing yang bertujuan untuk memperkenalkan danmembentuk citra suatu partaimaupunkandidat. Strategi yang digunakan pada politicalmarketing menggunakan kemasan khusus untuk menjadi sebuah daya tarik terhadap masyarakat. Strategi pesan digunakan untuk mengemas suatu pesan yang disampaikan agar mudah dimengerti oleh masyarakat, lalu strategi media digunakan sebagai alat penyebaran pesan untuk meyampaikan kepada khalayak berdasarakan target dari political marketing tersebut.

Program kampanye dalam Political marketing merupaka ajang promosi yang dilakukan oleh partai politik untuk mempromosikan kandidat calon pemimpin kepada masyarakat. Anies-Sandi membentuk sebuah program kampanye dengan cara positioning yaitu menacapkan citra tertentu terhadap calon pemilih agar tertarik pada dirinya maupun partai tersebut. Program kampanye yang di lakukan Anies-Sandi untuk membentuk suatu 
positioning ini ialah membangun image karakter dari Anies-Sandi yang terkesan humoris, sabar dan bersahaja.

Program kampanye Anies-Sandi merupakan suatu positioning yang dikemas berupa video dan dibagikan kepada masyarakat melalui media sosial. Vidio baca \#tweetjahat merupakan balasan dari Anies-Sandi dalam menanggapi serangan yang menjatuhkan image nya di dalam media sosial twitter. Anies-Sandi menanggapi serangan tersebut dengan gaya humoris, nyatanya dengan strategi ini pasangan Anies - Sandi berhasil memikat hati netizen yang menontonnya. Dengan program ini Anies - Sandi berhasil membangun citra dari karakter mereka yang disenangi oleh masyarakat dan program ini ikut ambil adil dalam kemenangan anies-sandi di PILKADA DKI 2017.

\section{REFERENSI}

Cangara, Hafied. 2009. Komunikasi Politik: Konsep, Teori dan Strategi. Jakarta: Raja Grafindo Persada

Fachrul, Zikri. 2015. Teori-Teori Komunikasi: Teori Komunikasi Dalam Perspektif Penenlitian Kualitatif. Bogor: Ghalia Indonesia

Firmanzah, 2012. Marketing Politik: Antara Pemahaman dan Realitas. Jakarta: Yayasan Obor Indonesia

Moleong, 2016. Metode Penelitian Kualitatif: Edisi Revisi. Bandung: PT Remaja Rosdakarya

Nimmo, Dan. 2008. Komunikasi Politik: Komunikator, Pesan, dan Media. Bandung: PT. Remaja Rosdakarya

Nursal, Adnan. 2004. Political Marketing: Strategi Memenangkan Pemilu. Jakarta: Gramedia Pustaka Utama.

Sandra, Lidya Joyce. 2013. Political Branding Jokowi Selama Masa Kampanye Pemilu Gubernur DKI Jakarta 2012 di Media Sosial Twitter. Jurnal EKomunikasi Vol I. NO.2 Tahun 2013

Sugiyono, 2015. Metode Penelitian Pendidikan: Pendekatan Kuantitatif, Kualitatif, dan $R \& D$. Bandung: Alfabeta

Suryanto. 2015. Pengantar Ilmu Komunikasi. Bandung: CV. Pustaka Setia 